\title{
The influence of nursing care on pregnancy and labour
}

\begin{abstract}
Introduction. Performance management is a crucial concept in the broader field of human resource management. In accordance with its principles, in defining a professional role, its aim must be included. In addition, key results areas and crucial competencies must be stated. The professional role of a nurse with regard to pregnancy and pre-natal care, is defined by way of the set of functions fulfilled. The role of a midwife and her competencies are, however, in this situation, much broader.

Aim. The aim of the conducted research was to determine the roles played by both nursing and midwifery staff in ensuring a healthy pregnancy and delivery by way of their patients' assessment.

Material and methods. The research was conducted in the Obstetrics and Gynaecology unit, in the Regional Specialist Hospital in Biała Podlaska, and it involved 40 pregnant women.

Results and discussion. Our study reveals that what the subject women need the most from the nursing and midwifery staff, is emotional support. What is more, the dominant majority connects their expectations as to the fulfilment of the roles played by nursing and midwifery staff to an increase in information support.

Conclusion. The obtained results allow a defining of the aim of the professional roles of nurses and midwives in supporting and assisting the pregnant, as well as identifying their key results areas and crucial competencies from the patients' point of view. In comparing our own study results to that involving patients' opinions (gained by way of a study conducted in the obstetrics and gynaecology unit, by the quality care assessment section of the Regional Specialist Hospital in Biała Podlaska), it can be stated that there is continuous positive growth in the quality of service provided by nurses and midwives.
\end{abstract}

Keywords: pregnancy, childbirth, nursing care.

DOI: $10.1515 /$ pjph-2015-0007

\section{INTRODUCTION}

Performance management is a prominent concept within the broader field of human resource management. It is a perpetual and flexible process which implies that managers and their subordinates work as a part of a partnership agreement which assigns how they should cooperate so as to achieve the results demanded. In terms of this cycle, the main actions involve defining a role, agreeing to the expected results, elaborating a personal development plan, following the current performance management guidelines, overviewing these, assessing the results and modifying these if necessary. The definition of a role indicates the confines within which performance management functions and involves the aim of the role, stated key results areas and crucial competencies [1].

The nursing profession came into being in 1860, when the first school of nursing was opened at St. Thomas' Hospital, in London, by its founder, Florence Nightingale, who claimed that nursing is both a calling and a preserve [2]. Nursing has evolved from that time and embarked on the path of searching and forming a set of professional roles in a way which allows its practitioners to adjust best to the individual needs and expectation of patients, their families, other social groups, and the greater society. In the modern world, nursing is becoming more and more an important field, aiming to provide people with better medical and socio-psychological help, along with ensuring the general population is in optimal health condition. For a long time, many misunderstandings have appeared as to what the profession actually is and some stereotypes have also emerged. What is more, the training, training standards and assessed professional competencies differed not only between particular countries, but also within one country. Indeed, not so long ago in Poland, the title could be obtained by graduating from a school of nursing or by simply finishing short courses or by undertaking specified work experiences and passing the national examination [3].

\footnotetext{
${ }^{1}$ Chair and Department of Public Health, Medical University of Lublin, Poland

${ }^{2}$ Regional Specialist Hospital in Biała Podlaska, Poland

${ }^{3}$ Medical University of Lublin, Poland
} 
Describing the professional role of a nurse is very difficult, considering the character of the practised profession and the dynamic development of the nursing profession as a whole. In the Encyclopaedia for Nurses and Obstetricians [4], the professional role of the nurse is defined as a followed relatively stable, patterned and internally coherent system of behaviour within the field of medicine involving the fulfilment of a set obligations to professional standards which poses a reaction for other people's behaviour. Of note, the nurses' professional role is conditioned upon the place allotted to the nursing field among the other medical professions. In general, a nurse fulfils certain medical/social functions. Among these are patient care, pedagogical, health promotion, preventative care, therapeutic and rehabilitative care [5]. The particular job of a nurse in the medical field of obstetrics is mainly focused on prophylaxis, but nurses also play a great role in diagnostics, treatment and rehabilitation.

Obstetrics as a field of medicine is closely related to gynaecology and aims at protecting the health of a pregnant woman and the developing fetus. It deals with theory and practice in the scope of pregnancy, labour and childbirth. In the literature on the subject [6], it is emphasized that this medical speciality uses the development and progress of other fields of medicine (such as, immunology, haematology, bacteriology and endocrinology) and technical sciences (for example, electronic-sensing and ultrasonography) to enable fetus monitoring so as to specify the placement of the fetus and its size, record the foetal heart function and uterine contraction, recognize placement and ascertain placental pathology, in order to provide necessary remedial action. In the field, however, the role played by the midwife is much broader, as their competencies involve prenatal care, managing labour and delivering the baby, as well as providing care of the woman and the baby during childbirth and immediately after.

Legal regulations concerning nurses and obstetricians are divided into two groups: that which is common, meaning those included in legislation; and that which is internal. Pursuant to Art. 2 of the Act of $15^{\text {th }}$ July 2011 on the nurse and obstetrics professions [7], practitioners belong within the self-governing medical professions. The internal legislative act in force governing this professional group is The Code of Professional Ethics for Nurses and Midwives of the Republic of Poland of $9^{\text {th }}$ December 2003 [8].

\section{AIM}

The aim of the conducted research was to determine the role of nursing and midwifery staff in ensuring a healthy pregnancy - as put forward by their patients. The research was undertaken to provide answers to three main intents: Determining what kinds of support nurses and midwives are giving to the respondents during pregnancy; Ascertaining how they assess the help; and Understanding their expectations with respect to the roles played by nursing and midwifery staff in ensuring proper prenatal $/$ natal/post-natal care.

\section{MATERIAL AND METHODS}

The research was conducted in the Obstetrics and Gynaecology unit within the Regional Specialist Hospital in Biała Podlaska, between 24.11.2004 and 30.1.2005. The research involved 40 pregnant women. It should be noted that 29 of the respondents were from urban areas and the remaining 11 were from rural areas. Moreover, the majority of the respondents were between the age of 21-30 (70\%), some respondents were aged between $31-40$ years $(20 \%)$, however, $10 \%$ were under 20 . The average age of the mothers-to-be was 26,3. In addition, a slight majority of the respondents were to be first-time mothers.

\section{RESULTS AND DISCUSSION}

The respondents (at $92.5-100 \%$ urban, $72.7 \%$ rural) put forward that their greatest need and request was for emotional support, including sustenance, friendliness, understanding, empathy and patience. Secondly (at 45-90\% - urban, 100\% rural), they stated a need for information support, including that on the growth of a baby, best lifestyle practices, hygiene and nutrition during pregnancy, and the explanation of issues connected to labour. The reason for this strong difference in need between rural and urban is the lack in rural areas of locally available information sources such health-care clinics, Internet connections, and published resources. Urban respondents, evidentially, had far better access to such information resources (of these, $24.1 \%$ stated that they looked for and found the necessary information on the Internet or in books and magazines). Instrumental support, meaning help during giving birth, was ranked third (at $45-48.3 \%$ urban, $36.4 \%$ rural).

The main source of emotional and information support, as well as the most trusted resource for the respondents, is their doctor $(92.5 \%$ overall). To a little less degree, but still quite high, these respondents placed their assessment of the roles played by their family $(77.5 \%)$ and the nursing and midwifery staff $(72.5 \%)$ during the course of their pregnancy. It should be emphasized that women from rural areas unanimously claim $(100 \%)$ that they were given the greatest emotional and information support by nurses and midwives, distinguishing at the same time, secondarily, the support given by their families (mainly husbands and mothers). Both urban and rural respondents listed as marginal, the informational and emotional support proffered by health-care clinics.

Over half of the respondents $(52.5 \%)$ stated a belief that the nursing and midwifery staff contributions to effective and appropriate care prenatally and during their labour is quite great (or prominent - as put forward by $35 \%$ of all interviewees). Moreover, the majority of the respondents highly appreciated the work of both nurses and midwives, as well as their positive influence on prenatal health (their own and their babies). However, some marginalized the role that these professions played. It is possible that their assessment of the contribution of the nursing and midwifery staff to the health and safety of both mother and child are the result of the reigning stereotypes, according to which these individuals are limited to giving injections, filling out medical cards or making up beds. 
The assessment of the help and care provided by nursing and midwifery staff during pregnancy and labour is, however, not polar $-55 \%$ of the respondents believe that nursing help and care is very good, while $45 \%$ of the women consider it to be adequate. What is more, the dominant majority of the respondents $(72.5 \%)$ state that their expectations as for the role which nurses and midwives should fulfil are associated with increasing the needed informational support. As far as emotional support is concerned, the respondents requested more understanding and friendliness $(55 \%$ and $42.5 \%$, respectively), patience (25\%), sustenance (20\%) and empathy (7.5). What is more, some subjects of the research stated an expectation for greater availability as a means of instrumental support (7.5\%). In analysing the obtained results, it can be assumed that apart from requiring extensive theoretical educational and practical qualifications in medicine for their professional credentials, nurses need emotional/ psychological training as well.

Nurses and midwives also exercise their profession, inter alia, by providing educational and health activities as far as PSHE education and birth control methods are concerned. Yet, only a scant percentage of the respondents made use of these professions knowledge of this subject matter. One of the possible reasons for this is the young age of the respondents. This assumes that their pregnancies were unplanned. Another cause might be a lack of tradition in family planning and in the treatment of this topic as taboo. However, at the same time, it can be observed that nurses and midwives are currently ill-prepared to provide such information.

The current state of medical development allows the treatment of infants prenatally, but to make this possible, malformations must be identified quite early. Examinations which monitor pregnancy serve this purpose. All the respondents stated that they were informed by the nursing staff they dealt with about the possibility of undertaking such tests, and, in some cases, some mothers-to-be stated that their necessity was emphasized, with the suggestion that doing so will allow them to avoid later complications.

Pregnancy carries the need to change practised lifestyles, meaning a lot of restrictions and new duties. Such changes should concern all spheres of life so as to ensure a healthy pregnancy and healthy off-spring. The majority of the respondents $(95 \%)$ noted that the nursing and midwifery staff they dealt with informed them of this need. Moreover, they stated that instruction was given in personal care, hygiene and rational nutrition during their pregnancies. They were also informed about the medical care that they will encounter.

A substantial majority of the respondents (85\%) stated that they would willingly attend classes organised by nurses and midwives which would inform them about the prophylaxis during pregnancy and prepare them for their labour (a so-called 'School of Birth'). Only 15\% of the women surveyed declared themselves unwilling to attend such courses. Available research points out [9] that women who go to a school of birth, more rarely decide to take papaverine, oxytocin or buscolysin during their labour, and the condition of their newborn children are, in $85 \%$ of all cases, given 10 points on the Apgar scale. Of note, all the interviewees (regardless of their place of living and the place of conducted research) believe that, undoubtedly, the greatest advantage of a school of birth is in making parents bound emotionally and in preparing them for the labour and for the conscious reception of their offspring. Nurses and midwives play specific and prominent roles in such kind of schools.

Almost concurrently to our research, in another obstetrics and gynaecology unit, surveys were conducted concerning patients' opinion with respect to the proffered medical help. These surveys date back to the year 1997, when the administration of Regional Specialist Hospital in Biała Podlaska initiated them. These involved an assessment of encountered nursing care, taking into consideration familiarization with patients' rights and the unit's status, proffered information about all medical means used and procedures performed, as well as information about the intent and the way of selfpreparation prior to the performance of the necessitated procedures, the act of informing about the possibility for the father of the baby or other close person to be present during labour, the maintenance of patients' privacy, the friendliness of midwives, the daily and nightly availability of midwives, and the quickness of their response to help requests. While assessing the nursing care, consideration was made to criteria like the sensibility and friendliness of the staff, the accuracy of performed nursing procedures and the availability of nursing staff.

According to this assessment of midwife and nursing care, it needs to be highlighted that their friendliness has been assessed as 'very good' by $72.6 \%$ of the women interviewed, as 'good' by $23.3 \%$ and as 'rather good' by the remaining $4.1 \%$. It should be noted that the derived data (from the year preceding our own research) allowed us to observe positive changes, as the friendliness of midwifery staff was then assessed as 'very good' by $63.6 \%$ of the women, 'good' by $31,9 \%$ and 'rather good' by $4.5 \%$. However, the sensibility and friendliness of the nursing staff were assessed a little worse; $45.2 \%$ of patients described these attributes as 'very good', $28.8 \%$ - as 'good' and $13.7 \%$ - as 'rather good'. The rest of the patients rated these as 'bad' and 'very bad' (9.6\% and $2.7 \%$, respectively). With respect to the availability of midwives during days and nights, this was assessed all good, just as was quickness of reaction to appeals for help. In comparison to this, the availability of nursing staff presents itself as being a little worse - as $6,8 \%$ of the interviewees rated it as 'bad', and another $4.2 \%$ rated this as being 'very bad', irrespective of the fact that in the dominating opinion ( $89 \%$ of the women), the nursing staff were readily available day and night as well (a positive change of 1 percent, in comparison to the preceding year). In the formal aspect, the respondents put forward that the staff fulfilled their duties very well. Of particular note was the work of the midwifery staff. All the respondents noted that they were made familiar with their rights and the unit's status. In addition, the substantial majority of the interviewees $(98.7 \%)$ stated that they were informed about the means used and procedures performed during their hospital stay. What is more, all of them were informed about the aim and the ways of preparing for the prenatal/birthing procedures, while $79.4 \%$ of them stated that they were informed about possible presence of father of the baby or other close person being allowed to be present during the labour and birth. The respondents openly 
replied too, that the midwifery staff cared about their intimacy $(84.9 \%$ of the responses were 'yes' answers and $10.9 \%$ were 'rather yes' ones), and that the nursing staff performed the necessary hospital procedures and practices carefully (36.9\% - 'very good', 42.5\% - 'good, $12.3 \%$ - 'rather good').

The fact itself that such surveys were conducted with due consideration of patients opinions of the nursing and midwifery staff, shows the importance of the role which is attached to nurses and midwives during pregnancy. It should be also mentioned that $30.1 \%$ of patients claimed the midwife to be the one person from the medical staff whom they could talk with about their worries and concerns (almost half of the women $(49.3 \%)$ of the interviewees stated, however, that they did not have such needs).

\section{CONCLUSIONS}

The obtained results allow the defining of the aim of the professional roles of nursing and midwifery staff, their key results areas and their crucial competencies from the patients' point of view. The nurses' and midwives' job in the subject hospital is highly appreciated by pregnant women. As is evident in our work, nurses and midwives support them emotionally and informationally, talking with them about their concerns and worries. The eagerness to attend courses organised by nurses and midwives bears witness to the great trust of pregnant women for the staff. In comparing the results of our own research to the results of the opinion polls conducted by the quality section of the Regional Specialist Hospital in Biała Podlaska within its obstetrics and gynaecology unit, it can be assumed that the described situation is the result of the continuous growth of nursing and midwifery services and professionalism which has come about through on-going training. This conclusion is supported by way of the positive assessment of the dynamics of changes concerning the main criteria of assessment during the period of the year preceding our own research.

\section{REFERENCES}

1. Armstrong M. Zarządzanie zasobami ludzkimi. Kraków: Oficyna Ekonomiczna; 2001.

2. Wrońska I. Determinanty rozwoju pielęgniarstwa. In: B. Ślusarska, D. Zarzycka, K. Zahradniczek (ed). Podstawy Pielęgniarstwa. Lublin: Wydawnictwo Czelej; 2004. p. 36-45.

3. Poznańska S. Pielęgniarka w opiece nad zdrowiem. In: K. Zahradniczek (ed). Pielęgniarstwo. Warszawa: Wydawnictwo Lekarskie PZWL; 2006. p. 39-56.

4. Widomska-Czekajska T, Górajek-Jóźwik J. Encyklopedia dla pielęgniarek i położnych. Warszawa: Wydawnictwo Lekarskie PZWL; 2010.

5. Ciechaniewicz W. Pielęgniarstwo ćwiczenia. Warszawa: Wydawnictwo Lekarskie PZWL; 2007.

6. Widomska-Czekajska T, Górajek-Jóźwik J. Przewodnik Encyklopedyczny dla Pielęgniarek. Warszawa: Wydawnictwo Lekarskie PZWL; 1996.

7. Ustawa z dn. 15 lipca 2011 r. o zawodach pielęgniarki i położnej, Dz. U. nr 174, poz. 1039 z późn. zm.

8. Kodeks Etyki Zawodowej pielęgniarki i położnej Rzeczypospolitej Polski z dn. 9 grudnia 2003 r., przyjęty uchwałą nr 9 na IV Krajowym Zjeździe Pielęgniarek i Położnych.

9. Łepecka-Klusek G. Pielęgniarstwo we współczesnym położnictwie i ginekologii. Lublin: Wydawnictwo Czelej; 2003.

Corresponding author

Joanna Kozłowiec

tel: 502384992

E-mail: j.kozlowiec@op.pl 